\title{
La interacción de la instrucción explícita del pensamiento crítico, el rendimiento de la escritura académica, la capacidad de pensamiento crítico y las disposiciones de pensamiento crítico: un estudio experimental
}

\section{The Interplay of Critical Thinking Explicit Instruction, Academic Writing Performance, Critical Thinking Ability, and Critical Thinking Dispositions: An Experimental Study}

\author{
Ali Taghinezhad. \\ Islamic Azad University, Irán. \\ taghinezhad1@gmail.com \\ Mohammad Javad Riasati. \\ Islamic Azad University, Irán. \\ miriasati2002@yahoo.com
}

\section{RESUMEN.}

El presente estudio tuvo la intención de investigar la interacción de la enseñanza explícita del pensamiento crítico, el rendimiento de la escritura académica, la capacidad de pensamiento crítico y las disposiciones de pensamiento crítico de los estudiantes iraníes. Con este fin, se seleccionaron 140 estudiantes de la Universidad de Ciencias Médicas de Jahrom (73 hombres y 67 mujeres). Se dividieron en los grupos experimentales y de control. Ambos grupos recibieron instrucción en cursos de escritura académica durante 15 semanas 3 horas por semana. A los estudiantes de ambos grupos se les administraron pruebas previas y posteriores a la instrucción para examinar la efectividad de la instrucción. Se utilizaron tres instrumentos en este estudio, incluyendo la prueba de ensayo desarrollada por el investigador, la Prueba de ensayo de pensamiento crítico Ennis-Weir y el Inventario de disposiciones de pensamiento crítico de California (CCTDI). La estadística descriptiva y la prueba t de muestras independientes se utilizaron para analizar los datos. Los resultados indicaron que hubo diferencias estadísticamente significativas entre las puntuaciones medias de los grupos experimental y control. Los resultados también mostraron que algunas subescalas de CCTDI no fueron significativamente diferentes en la prueba posterior, como la búsqueda de la verdad, la madurez cognitiva y la mentalidad abierta, mientras que las puntuaciones medias posteriores a la prueba de otras subescalas de CCTDI fueron significativamente diferentes, como curiosidad por TC, CT confianza en sí mismo y sistemática. El grupo experimental tuvo una puntuación más alta en la prueba de escritura académica en comparación con el grupo de control. Los cambios en la capacidad de pensamiento crítico de los estudiantes, el rendimiento de la escritura académica y sus disposiciones de pensamiento crítico sugieren que las técnicas de CT han sido fructíferas, y se deben hacer más esfuerzos para integrar la instrucción explícita en pensamiento crítico en los cursos académicos. 


\section{PALABRAS CLAVE.}

Rendimiento académico de escritura, inventario de disposiciones de pensamiento crítico, instrucción explícita de pensamiento crítico, prueba de ensayo de pensamiento crítico de Ennis-Weir.

\section{ABSTRACT.}

The present study intended to investigate the interplay of critical thinking explicit instruction, academic writing performance, critical thinking ability, and critical thinking dispositions of Iranian students. To this end, 140 students of Jahrom University of Medical Sciences (73 males and 67 females) were selected. They were divided into the experimental and the control groups. Both groups received instruction in academic writing course for 15 weeks 3 hours per week. The students in both groups were administered pre- and post-instruction tests in order to examine the effectiveness of the instruction. Three instruments were utilized in this study including, the researcher-developed essay test, the Ennis-Weir Critical Thinking Essay Test, and the California Critical Thinking Dispositions Inventory (CCTDI). Descriptive statistics and independent-samples t-test were used to analyze the data. The results indicated that there were statistically significant differences between the mean scores of the experimental and the control groups. The results also showed that some CCTDI subscales were not significantly different at the posttest such as, truth-seeking, cognitive maturity, and open- mindedness, whereas the mean posttest scores of other CCTDI subscales were significantly different such as, analyticity, CT inquisitiveness, CT self-confidence, and systematicity. The experimental group had a higher score in the academic writing test compared with the control group. Changes in students' critical thinking ability, academic writing performance, and their critical thinking dispositions suggest that the CT techniques have been fruitful, and more efforts should be made to integrate the explicit instruction in critical thinking into academic courses.

KEY WORDS. Academic Writing Performance, Critical Thinking Dispositions Inventory, Critical Thinking Explicit Instruction, Ennis-Weir Critical Thinking Essay Test.

\section{Introduction.}

The instruction of cognitive skills such as critical thinking is not a completely new phenomenon. It originated from Greek philosophy and received Dewey's (1933) support after the Second World War. It was modified by Bloom in the 1950s and became popular in the 1990s. From Socratic era to contemporary concerns about educated citizens and highquality workforces, the ability to think critically and to think rationally is regarded as the primary and necessary result of education (Reed, 1998). Today, the world needs people with critical thinking qualities to meet the ever-increasing life challenges. Prerequisite for employment in the global economy, the survival of democratic lifestyles, and personal decision-making in a complex and rapidly changing society require individuals who can reason well and make sound judgments. As a country moves toward a technology-based economy, it needs trained personnel who can face global competition, meet employers' 
needs, be flexible and analytic in thinking, integrate information from a myriad of sources and perspectives, and can effectively make profitable and efficient decisions. Psychologists, philosophers, and educators (Halpern, 2007; King, 1994) believe that making rational decisions needs the ability to analyze, evaluate, interpret, and synthesize information accurately from various sources, and it is an indispensable tool for successfully accomplishing tasks in a complex and ever-changing world for students, staff, and citizens. Developing critical thinking skills among undergraduates is an essential life skill that has received extraordinary attention in the past two decades. Critical thinking can be developed among college students (Halpern, 1998; Tsui, 2002), especially if critical thinking instruction and student practice are permeated throughout the curriculum (Condon and KellyRiley, 2004).

Despite widespread expression of concern for the development of critical thinkers, observations and current empirical studies show that most schools, colleges, and universities neither challenge the students to think critically about academic subjects nor do they help them develop reasoning abilities to succeed in dealing with the difficulties of modern life. Although active learning methods or student-centered teaching which help students think about what they do would dominate the educational practices of schools and universities our education system still provides

students with traditional teaching models. The erroneous daily reasoning and poor debate techniques used by most students (verbally and in writing) suggest that even university education seems to have a limited impact on the critical thinking ability of students, including the rational interpretation of texts and formulation of unbiased arguments. The possible reasons for this shortcoming are as follows: (a) Teachers do not receive critical thinking training when they are in college education, and they do not even know what critical thinking means. (b) There are few or no standard textbooks and/or reference books in critical thinking. (c) Teachers do not have the time and teaching resources to incorporate critical thinking skills into their classroom teaching methods (d). Teachers teach implicitly rather than explicitly. These shortcomings are very important because critical thinking is highly relevant to students' achievement.

Like many other countries, the education policy implemented in Iran vividly shows that the pedagogical implications of constructivism would influence the teaching practices in schools. However, the available empirical evidence shows that education in Iran is still characterized by traditional teaching methods. Unfortunately, traditional education models just allow students to receive rather than seek knowledge. In this teaching mode, the spread of knowledge is considered authoritative and can be passed from teacher to student. It is assumed that knowledge and procedures must be instilled in students who are passive recipients during the learning process (Ramsden and Moses, 1992). This approach also reinforces the importance of traditional implicit models that provide critical thinking instruction and simply regard critical thinking as an implicit goal of the curriculum (Reed, 1998; Pescatore, 2007).

Lack of enough empirical data regarding the students' critical thinking and its approach to language education shows the necessity for this study. Such a study can provide some useful information about the teaching of Critical Thinking and EFL in general and academic 
writing skills in particular. Conducting such a study can be significant for the following reasons:

Firstly, although research on the students' critical thinking has been underway in other countries such as the United States and Europe, no study has been conducted so far on the undergraduate students' critical thinking in Iran. Thus, this study can provide an impetus for the teaching profession to follow a systematic approach to developing a critical thinking pedagogy in language education.

Secondly, even though much research has been done on critical thinking approach to learning, very little is known about its effect on the students' academic writing abilities. Moreover, although the effect of critical thinking on general education has been indicated, it is unclear whether its effect will be repeated when critical thinking strategy is applied to different subject areas. This study can help language educators and curriculum designers understand the fact that critical thinking could be the basis for designing programs and course materials that can boost the students' learning.

Therefore, this study intends to answer the following questions:

1. Does explicit critical thinking strategy instruction help Iranian students outperform in their writing ability?

2. Do Iranian students who receive explicit instruction in critical thinking techniques have different dispositions toward the use of essential skills of thinking compared to those not receiving explicit instruction in essential techniques of thinking?

3. Does explicit instruction in critical thinking techniques have any effect on students' dispositions toward the use of essential skills of thinking?

4. Is there any relationship among Iranian EFL students' writing skill, critical thinking ability, and dispositions toward critical thinking?

\section{Literature Review.}

Critical Thinking (CT) is not a new term. The intellectual origins of CT can be traced back to about 2,400 years ago to Socrates' teaching practice who underlined the significance of questioning which is now called Socratic questioning, a strategy for teaching CT (Paul, 1985). Socrates set the agenda for CT tradition to reflectively question common beliefs and interpretations and carefully distinguish those beliefs that are rational from those that lack sufficient evidence or rational basis (Paul \& Elder, 2008). Socrates' approach was followed by Plato, Aristotle and Greek skeptics who valued the significance of seeing through the chimerical appearance of the deeper realities of life. The CT tradition lasted for centuries until the CT movement in the early 1980s, when CT research in philosophy, psychology, and education broke out (Fasko, 2003). The approaches used to define CT in philosophy, psychology, and education are different (see Table 1). The philosophical approach focuses on the application of formal rules of logic (Lewis \& Smith, 1993) and emphasizes the quality and standards of thinking. It assumes the best performance of ideas that might not be in line with reality (Sternberg, 1986). 
Table 1. Definitions of CT in Philosophy, Psychology and Education

\section{Philosophy}

Act of persistent and careful consideration of any belief or supposed form of knowledge in the light of the grounds that support it and the further conclusions to which it tends. (Dewey, 1933, p. 9)

$\square$ The propensity and skill to engage in an activity with reflective skepticism. (McPeck, 1981, p. 8)

$\square$ Reasonable reflective thinking that is focused on deciding what to believe or do. (Ennis, 1985, p. 45)

$\square$ Skillful, responsible thinking that facilitates good judgement because it 1) relies upon criteria, 2 ) is self-correcting, and 3 ) is sensitive to context. (Lipman, 1988, p. 39)

Purposeful, self-regulatory judgement which results in interpretation, analysis, evaluation, and inference, as well as explanation of the evidential, conceptual, methodological, criteriological, or conceptual considerations upon which that judgement is based. (Facione, 1990, p. 3)

Disciplined, self-directed thinking that exemplifies the perfections of thinking appropriate to a particular mode or domain of thought. (Paul, 1992, p. 9)

\section{Psychology}

The extension of evidence in accord with that evidence so as to fill up gaps in the evidence.

(Bartlett, 1958, p. 75)

$\sqsubset \quad$ An active process involving a number of denotable mental operations such as induction, deduction, reasoning, classification and definition of relationships. (Siegel, 1988, p.

$\sqsubset \quad$ The mental processes, strategies, and representations people use to solve problems, make decisions, and learn new concepts.

(Sternberg, 1986, p. 3)

$\sqsubset \quad$ A set of processes whereby people assemble, use and revise internal mental symbols.

(Gilhooly, 1996, p. 1)

$\sqsubset \quad$ The use of those cognitive skills or strategies that increase the probability of a desirable outcome. (Halpern, 1998, p. 450)

$\sqsubset \quad$ Seeing both sides of an issue, being open to new evidence that disconfirms your ideas, reasoning dispassionately, demanding that claims be backed by evidence, deducing and inferring conclusions from available facts, solving problems, and so forth. (Willingham, 2008, p. 8)

\section{Education}

Analysis, synthesis, evaluation. (Bloom,

An investigation purpose is to explore situation, question, or problem arrive at a hypothesis conclusion about it integrates all available information and that therefore be justified. (Kurfiss, p. 2)

Making reasoned judgements. (Beyer, p. 8)

$\square \quad$ The propensity and to engage in activity reflective skepticism focused on deciding to believe or do. (Halonen, 1995, p. 76)

Take new information interrelate and/or rearrange and extend information to achieve purpose or find answers in perplexing situations. (Lewis \& Smith, 1993, p. 136)

Skills which enable individuals to solve problems for which have no ready-made procedures or (Steele, 1997, p. 6) 


\subsection{CT Skills and CT Dispositions.}

Although there are differences in the three viewpoints about CT definition, there are some common points. Firstly, researchers tend to identify certain skills that are closely related to the concept of CT. Secondly, researchers believe that CT involves not only skills but also dispositions. It requires a further exploration of prevailing definitions to determine specific CT skills and CT dispositions and their relationships.

\subsection{CT Skills.}

The common conceptualization of CT relates it to a set of cognitive skills. More precisely, CT skills are called higher-order cognitive skills (Halpern, 2007), which need a higher level of complexity of thinking skills. In order to more clearly explain the skills required for CT, researchers such as Bloom, Ennis, and Facione have invested considerable effort in providing the taxonomies of CT skills (see Table 2). Although the number of skills and the ways of categorization of those skills are different, they provide us with a more tangible conceptualization of CT by presenting a list of skills involved in the abstract thinking process. These skills cannot only be taught, but they are also observable and assessable. If we have a bird's eye view of all these definitions and classifications, it is not difficult to find several skills that most researchers value highly, whether it is from philosophy, psychology or education. These skills which are listed in the Table 3, involve making judgments or decisions, reasoning, evaluation and analysis. The claim that these are the most important CT skills may not be definite. However, the agreement reached on these skills implies a generally accepted view that CT is a utilization of skills such as reasoning, evaluating, or analyzing in thinking which aims to enhance the quality of thinking in the judgment and problem solving process.

Table 2. Taxonomies of CT Skills

\begin{tabular}{|c|c|c|}
\hline Bloom (1956) & Ennis (1985) & Facione (1990) \\
\hline $\begin{array}{ll}\text { - } & \text { Analysis } \\
\text { - } & \text { Synthesis } \\
\text { - } & \text { Evaluation }\end{array}$ & $\begin{array}{ll}\text { - } & \text { Focusing on a question } \\
\text { - } & \text { Analyzing arguments } \\
\text { - } & \text { Asking and answering questions of } \\
\text { - } & \text { Judarificationion and/or challenge } \\
\text { - } & \text { Observing and judging observation } \\
\text { - } & \text { Deports, criteria } \\
\text { - } & \text { Inducing and judging inductions } \\
\text { - } & \text { Making value judgments } \\
\text { - } & \text { Defining terms, and judging } \\
\text { - } & \text { definitions in three dimensions } \\
\text { - } & \text { Deciding on an action } \\
\text { - } & \text { Interacting with others }\end{array}$ & $\begin{array}{ll}\text { - } & \text { Interpretation } \\
\text { - } & \text { Analysis } \\
\text { - } & \text { Evaluation } \\
\text { - } & \text { Inference } \\
\text { - } & \text { Explanation } \\
\text { - } & \text { Self-Regulation }\end{array}$ \\
\hline
\end{tabular}




\subsection{CT Dispositions.}

long with the agreement on the idea that CT has a set of cognitive skills, researchers increasingly believe that CT also involves dispositions, which are, as defined by Facione (2000), "consistent internal motivations to act toward or respond to persons, events, or circumstances in habitual, yet potentially malleable ways" (p. 64). Delphi research experts warn that those who are proficient in CT skills but fail to use them properly are not good critical thinkers (Facione, 1990). Dewey (1933) emphasized the importance of attitudes. He pointed out that people tend to believe the facts that are consistent with their desires because their personal attitudes have not been examined. He stated that if we are forced to make a choice between personal attributes and the knowledge of logical reasoning principles along with a certain degree of technical skill in manipulating particular logic processes, we should select the former. When it comes to CT teaching in the educational milieu, special emphasis is placed on the CT dispositions as necessary factors for understanding CT instruction and as the final aim of teaching CT (Facione, Sánchez, Facione, and Gainen, 1995).

As Ennis (1985) shows, critical thinking ability is different from critical thinking disposition. Researchers from different fields of knowledge have attempted to describe the dispositions that an ideal critical thinker should have. Dewey (1933) proposed three personal attitudes. These three personal attitudes are a basic part of the general willingness to think in a thoughtful manner: wholeheartedness, open-mindedness, and responsibility. Many other researchers (e.g. Ennis, 1987; Halpern, 1998) advocating for emphasis on CT dispositions also provide a list of CT dispositions. Just as in the case of CT skills, although there is no consensus on a comprehensive list of CT dispositions, several intellectual traits are of great significance for being a critical thinker, such as open-mindedness, inquisitiveness, fairmindedness, propensity to seek alternatives, and respect for reason.

Interestingly, it has been found that these prominent dispositions are to some extent overlapping in nature. For example, open-mindedness, as defined by Dewey (1933), is "freedom from prejudice, partisanship, and such other habits as close the mind and make it unwilling to consider new problems and entertain new ideas" (p. 30). It expresses a meaning of fairness. Paul and Elder (2001) define it as unbiased and unprejudiced. Dewey also stated that open mindedness also includes actively listening to multiple opinions, paying attention to other possibilities, and recognizing the possibility of mistakes in one's beliefs, as well as alertness to the spontaneous outreaching for new things. In this sense, it also includes a disposition to seek alternatives and curiosity. Nonetheless, this does not mean that critical thinking dispositions come down to open-mindedness, because it does not encompass all the virtues that critical thinkers should possess. It can be concluded from all these arguments that the essence of being a critical thinker does not mean being rigorous, but rather being aware of the possible mistakes an individual might make, of the diversity of possible solutions, and the ways to achieve fair results. Considering that disposition is an important part of CT, this shows the fact that CT should be seen as not just a set of thinking skills, but should also recognize why and how to use these skills and the willingness of using them where appropriate. This recognition reminds us that, on the one hand, CT arises only

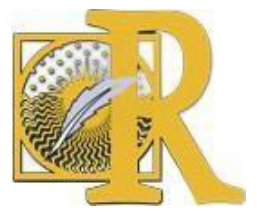


when people use it; on the other hand, the key and important goal of CT teaching is to encourage students' CT dispositions.

\subsection{The Relationship Between CT Skills and CT Dispositions.}

A glance at the definitions of CT identifies two basic aspects of CT and reveals that a thorough understanding of CT should include skills and disposition. Facione et al. (1995) assume that CT skills and CT disposition reciprocally reinforce each other. However, the connection between CT skills and CT dispositions is not a one-to-one correspondence, which means that skills-centered

Courses do not lead to learners willing to think critically, because being skilled does not guarantee that someone is using CT, and having disposition toward critical thinking does not guarantee that the person is skilled (Facione, 2000). The relationship between CT skills and CT dispositions reveals two principles about what and how to teach CT. First of all, the teaching of CT involves not only the development of CT skills but also the cultivation of CT dispositions, so that learners can not only use CT skills in an appropriate setting, but also are willing to use CT skills. Second, although the teaching of CT skills and CT disposition should not be separated, skills and dispositions are two distinct things (Facione, 2000). Hence, different approaches should be used for each aspect.

An investigation of the perception of CT shows the complexity of the concept, which implies possible challenges to introduce CT into the classroom context. With regard to the actual teaching practice, what teachers want is more than one definition, but an established model that can present a set of tools to facilitate the teaching and learning of CT in different disciplines (Jones \& Haydon, 2012).

Table 5. Paul and Elder's (2001) CT Model.

\begin{tabular}{llcl} 
Elements of thought & Intellectual standards \\
\hline$\square$ & Purpose & $\square$ & Clarity \\
$\square$ & Question at issue & & Accuracy \\
$\square$ & Information & $\square$ & Precision \\
$\square$ & Interpretation & $\square$ & Relevance \\
$\square$ & Concepts & & Depth \\
$\square \quad$ & Assumptions & $\square$ & Breadth \\
$\square \quad$ & Implications and & & Logic \\
& consequences & $\square$ & Significance \\
$\square \quad$ Point of view & $\square$ & Fairness \\
& &
\end{tabular}

Intellectualtraits

$\begin{array}{ll}\sqsupset & \text { Fair-mindedness } \\ & \text { Intellectual humility } \\ \sqsupset & \text { Intellectual courage } \\ \sqsupset & \text { Intellectual empathy } \\ & \text { Intellectual integrity } \\ \sqsupset & \text { Intellectual perseverance } \\ & \text { Confidence in reason } \\ \sqsupset & \text { Intellectual autonomy }\end{array}$

Considering CT as the art of analyzing and evaluating thinking with regard to its improvement (Paul \& Elder, 2007), Paul and the Elder presented a 3D model of CT that includes not only CT skills and CT dispositions, but also standards which evaluate the quality of thinking. They believe that critical thinkers regularly use intellectual standards for the elements of reasoning to develop intellectual traits (Paul and Elder, 2001), Paul and the Elder provided three components in their CT model (Table 5): (1) elements of thought; (ii) intellectual standards; and 3) Intellectual traits. 


\section{Method.}

\subsection{Research Design.}

This research study is a 2-group quasi-experimental pretest/posttest control group design.

Students were assigned to experimental and control groups. A quasi-experimental pretest/posttest control group design was utilized for this study to determine whether students receiving the critical thinking instruction would perform differently from those in the non-critical thinking group.

\subsection{Participants.}

The current study was carried out in Jahrom University of Medical Sciences, Iran. 140 sophomore medical students participated in this study. They were male and female students studying advanced English writing course at Jahrom University of Medical Sciences. They were from 18 to 25 years of age. The students were selected using convenient (purposive) sampling technique. They were divided into experimental (critical thinking) and control (noncritical thinking) groups.

\subsection{Instruments.}

The instruments that were used in this study are as follows:

\section{a) The Researcher-developed Essay Test.}

An essay writing test was developed to examine whether students who are exposed to explicit instruction in critical thinking perform better in a test that requires them to analyze and interpret topics and write essays than those who do not receive explicit instruction in critical thinking. It is assumed that such a writing test is more comprehensive and can evaluate more aspects of critical thinking. For this purpose, a topic is assigned, and students are required to write so that the researcher can examine whether explicit instruction in critical thinking in the writing course can enhance the students' performance in essay writing skills. Because of the subjective nature of marking an essay, inter-rater reliability can be an inevitable problem. Therefore, the reliability of the essay writing skill test must be measured to make sure that coders assign the essay

test ratings consistently.

\section{b) The Ennis-Weir Critical Thinking Essay Test.}

The second instrument used in this study was the Ennis-Weir Critical Thinking Essay Test (CTET) developed by Ennis and Weir (1985). Although there are several instruments which test critical thinking abilities, this instrument is the most significant instrument for teaching and testing purposes (Ennis \& Weir, 1985). It is an open-ended test because critical thinking is an open-ended activity (Ennis \& Weir, 1985) that can help evaluate an individual's general ability to assess an argument and to make an argument in response. The reliability of the Ennis-Weir CTET has been calculated to be from 0.72 to 0.99 (Ennis, 2005).






\section{c) The California Critical Thinking Dispositions Inventory (CCTDI).}

The third instrument used in this study was the California Critical Thinking Dispositions Inventory (CCTDI). The aim of this instrument was to determine whether the students who receive explicit instruction in critical thinking strategies have different dispositions towards their critical thinking abilities compared to those who do not receive any instruction. This is the first instrument which has been devised for this purpose, and it is conceptually rooted in the Delphi Report on Critical Thinking (American Philosophical Association, 1990). This inventory has seven dimensions and 75 items with a Likert scale type. The seven dimensions of this instrument are systematicity, open-mindedness, analyticity, truth-seeking, inquisitiveness, critical thinking, self-confidence, and cognitive maturity.

\subsection{Data Collection.}

Students were assigned to the control and the experimental groups. The CCTDI, the academic writing test, and the Ennis-Weir Critical Thinking Essay were used to collect data in two phases (pretest and posttest). The students in the experimental and the control groups received instruction in academic writing 3 hours per week for one semester. The instructor gave the students a pretest at the end of the first week of instruction. The instruction then continued for 15 weeks.

\subsection{Instructional Method and Materials.}

\subsubsection{Experimental Group.}

In order to examine the possible impacts of incorporating explicit instruction of critical thinking into academic writing curriculum on Iranian university students' writing performance, students were assigned to experimental and control groups. The APA Delphi Report on Teaching for Critical Thinking and Assessment (Facione, 1990) was utilized as the basis for the experimental treatment in the present study. The instructor integrated the critical thinking techniques into the content of academic writing course in the experimental group via (a) providing CT explicit instruction, (b) teaching students how to make use of those techniques to synthesize, analyze, and evaluate texts, (c) presenting support materials in CT classrooms (including leaflets, models) of the instructional techniques, (d) leading Socratic discussions based on the elements and criteria suggested in the instructional techniques, (e) assigning classroom activities and giving them adequate time to practice each skill, using both oral and written techniques, and assessing students' performance.

Students used two academic EFL writing materials (Table 6). One of these materials, nevertheless, was revised by the instructor to be used in the experimental group. Classroom assignments for the two groups were the same except integrating CT activities into classroom writing assignments explicitly to the experimental group.

The instructor provided the students in the experimental group with a package of critical thinking skills and explained to them. It included the definition of CT and CT skills, efficient techniques for developing critical thinking skills and habits of mind, and Critical Thinking Classroom Support. The instructor helped them create critical thinking skills to have a better performance in their academic and in everyday life situations. The package from




which students could select a strategy to use in a specific situation was borrowed from Paul's model and was taught to students in the experimental group. The package included CT skills and abilities (i.e. evaluation, analysis, explanation, inference, interpretation, and self-regulation (exceptional to Delphi Report)), the basics of reasoning: the goal of thinking, the problem to be solved, concepts and principles, information, frame of reference, perspective, inferences and solutions, assumptions and implications.

The instructor focused on critical thinking strategies in the experimental group. Firstly, the instructor utilized scaffoldded specific strategies of CT which commenced with rudimentary questioning strategies and ended with higher-order CT skills. He told the students that successful academic writing requires evaluation of information and the author's tone, data analysis, paraphrasing, and summarizing. Academic writers are expected to express their own points of view on the issue after summarizing the information. The students were asked to use elements of reasoning when reading texts and they were encouraged to share views about the text. This collaborative activity helped them better comprehend what types of reasoning were expected of them and improve their understanding of academic writing skills. In the experimental class, besides having Socratic discussions on the specified issues, the students were required to give a lecture for approximately 10-15 minutes. In order to enhance the students' critical thinking and academic writing ability, the instructor adopted a comprehensive explicit teaching method, with the following textbooks and other supplementary reading materials:

Textbooks:

1. Teaching Academic ESL Writing: Practical Techniques in Vocabulary and Grammar (Hinkel, 2003), and

2. The Write Stuff: Thinking Through Essays (Sims, 2014).

\subsubsection{The Control Group.}

Students in the control group were taught the same academic writing course materials as the experimental group. However, the two groups followed different instructional approaches for evaluating and analyzing the materials. Instead of teaching students to use the reasoning skills to analyze sources, the instructor asked the students in the control group to complete the questions at the beginning and at end of the sources. However, in order to be able to answer all the questions, students needed to use the elements of reasoning and use academic writers' strategies for comprehending sources in academic articles. The crucial differences between the approaches used in the control group and in the experimental group were the explicitness of $\mathrm{CT}$ i n s t r u ction in the experimental group. The instructor attempted to use the same activities in both groups except for the materials of CT instruction. The instruction time was the same both groups. 
Students in both the experimental and the control groups were given the same topic and required to write about it as a post-instruction test. Then, the Ennis-Weir CTET and the CCTDI were administered to them. Having coded and marked the tests data, the researcher analyzed the data using appropriate statistical procedures.

\subsection{Data Analysis.}

The means and standard deviations for the three instruments, namely Academic Writing Skills Test (AWST), Ennis-Weir Critical Thinking Essay Test, and the CCTDI are presented in Table 4. There were 73 students in the experimental group and 67 students in the control group.

Table 4. Descriptive Statistics of the Pretest and the Posttest Scores of the Instruments.

\begin{tabular}{|l|l|l|l|l|l|l|l|l|}
\hline \multirow{3}{*}{ Instrument } & \multicolumn{3}{|l|}{ Experimental Group (n = 73) } & \multicolumn{4}{l|}{ Control Group (n = 67) } & \\
\cline { 2 - 9 } & Pretest & Posttest & Pretest & Posttest \\
\cline { 2 - 10 } & Mean & SD & Mean & SD & Mean & SD & Mean & SD. \\
\hline AWST & 51.32 & 13.72 & 74.68 & 5.92 & 51.63 & 7.58 & 56.49 & 12.17 \\
\hline Ennis-Weir CTET & 43.57 & 7.04 & 71.42 & 6.84 & 44.32 & 5.72 & 53.78 & 7.96 \\
\hline CCTDI (Total) & 279.58 & 29.87 & 316.38 & 26.42 & 278.12 & 23.85 & 292.82 & 13.87 \\
\hline
\end{tabular}

The results of the descriptive statistics as indicated in Table 4 show that the mean pretest of the experimental group is approximately the same as the mean pretest scores found in the control group, demonstrating that the two groups had similar background before the intervention. Nevertheless, there was a significant difference between the experimental and the control groups regarding the pretest and the posttest scores. The experimental group had a higher gain on all instruments on the posttest compared to the control group which had a trivial change from pretest to posttest.

\subsubsection{Impact of Explicit Instruction in Critical Thinking on Student's Writing Performance}

In order to explore the impact of CT explicit instruction on students' writing performance, an independent-samples t-test was run. The significance level was set at $P<0.05$. Table 5 provides the result of the t-test. 
Table 5. The independent-samples t-test for the experimental and the control groups regarding essay writing.

\begin{tabular}{|c|c|c|c|c|c|c|c|c|}
\hline & Group & $\mathrm{N}$ & Mean & SD & SE mean & t-value & $\mathrm{df}$ & $\mathrm{P}$ (sig.2-tailed) \\
\hline Posttest & $\begin{array}{l}E \\
C\end{array}$ & $\begin{array}{l}73 \\
67\end{array}$ & $\begin{array}{l}77.68 \\
56.49\end{array}$ & $\begin{array}{l}5.92 \\
12.1\end{array}$ & $\begin{array}{l}1.17932 \\
1.71634\end{array}$ & 7.147 & 138 & $.001^{*}$ \\
\hline
\end{tabular}

Significant at $p<0.05$ (2-tailed)

According to Table 5, there was a statistically significant difference between the experimental group and the control group with regard to their writing performance $(P<0.05)$. The mean of the experimental group was significantly higher $(M=77.68, S D$ $=5.92)$ compared to that of the control group $(M=56.49, S D=12.1)$. The effect size of the difference in the academic writing skills test was calculated at Cohen's $d=1.67$, demonstrating a very large effect size.

\subsubsection{The Impact of CT Explicit Instruction on Students' Dispositions Toward CT.}

Table 6 provides the results of descriptive statistics on the CCTDI. According to Table 6, there was a trivial difference between the mean pretest of the experimental group $(\mathrm{m}=$ $279.58)$ and that of the control group $(m=278.12)$. Nonetheless, the gains at the posttest in both groups were higher than those of the pretest. According to Table 6 , the experimental group had a more remarkable improvement from pretest to posttest, though students' gains in both groups had an increase from pretest to posttest.

Table 6. Descriptive Statistics of the Experimental and the Control Groups on the CCTDI

\begin{tabular}{|c|l|l|l|l|l|c|}
\hline \multicolumn{4}{|c}{} & \multicolumn{2}{c|}{ Pretest Scores } & \multicolumn{2}{c|}{ Posttest Scores } \\
\hline Instrument & Group & $\mathrm{N}$ & Mean & SD & Mean & SD \\
\hline CCTDI (Total) & Experimental & 73 & 279.58 & 29.87 & 316.38 & 26.42 \\
\cline { 2 - 7 } & Control & 67 & 278.12 & 23.85 & 292.82 & 13.87 \\
\hline
\end{tabular}

In order to examine whether the mean of the two groups were significantly different in posttest due to instruction or not, an independent-samples t-test was used. Table 7 provides the results of the t-test. 
Table 7. Independent-Samples t-test for Students' Dispositions Toward Critical Thinking

\begin{tabular}{|c|c|c|c|c|c|c|c|c|}
\hline Sub-scales & Group & $\mathrm{N}$ & Mean & SD & SE Mean & t-value & df & Sig.2-tailed \\
\hline Truth-seeking & $\begin{array}{l}\mathrm{E} \\
\mathrm{C}\end{array}$ & $\begin{array}{l}73 \\
67\end{array}$ & $\begin{array}{l}45.2145 \\
44.3697\end{array}$ & $\begin{array}{l}8.2136 \\
6.1637\end{array}$ & $\begin{array}{r}.4712 \\
.9147\end{array}$ & 1.627 & 138 & .231 \\
\hline Open-mindedness & $\begin{array}{l}E \\
C\end{array}$ & $\begin{array}{l}73 \\
67\end{array}$ & $\begin{array}{l}43.4153 \\
42.3265\end{array}$ & $\begin{array}{l}5.4791 \\
4.8749\end{array}$ & $\begin{array}{l}.8994 \\
.9461\end{array}$ & 1.598 & 138 & .219 \\
\hline Analyticity & $\begin{array}{l}\mathrm{E} \\
\mathrm{C}\end{array}$ & $\begin{array}{l}73 \\
67\end{array}$ & $\begin{array}{l}45.4789 \\
40.2179\end{array}$ & $\begin{array}{l}6.3685 \\
4.9725\end{array}$ & $\begin{array}{l}.7498 \\
.8124\end{array}$ & 3.712 & 138 & $.003^{*}$ \\
\hline Systematicity & $\begin{array}{l}E \\
C\end{array}$ & $\begin{array}{l}73 \\
67\end{array}$ & $\begin{array}{l}50.1794 \\
43.7317\end{array}$ & $\begin{array}{l}5.4632 \\
5.4971\end{array}$ & $\begin{array}{l}.7364 \\
.7968\end{array}$ & 5.212 & 138 & $.000^{*}$ \\
\hline $\begin{array}{l}\text { CT Self- } \\
\text { Confidence }\end{array}$ & $\begin{array}{l}\mathrm{E} \\
\mathrm{C}\end{array}$ & $\begin{array}{l}73 \\
67\end{array}$ & $\begin{array}{l}43.7419 \\
38.9412\end{array}$ & $\begin{array}{l}3.4123 \\
5.3497\end{array}$ & $\begin{array}{l}.7146 \\
.8794\end{array}$ & 4.897 & 138 & $.000^{*}$ \\
\hline CT Inquisitiveness & $\begin{array}{l}\mathrm{E} \\
\mathrm{C}\end{array}$ & $\begin{array}{l}73 \\
67\end{array}$ & $\begin{array}{l}48.3263 \\
43.0179\end{array}$ & $\begin{array}{l}5.6514 \\
5.0912\end{array}$ & $\begin{array}{l}.8971 \\
.7649\end{array}$ & 3.964 & 138 & $.002^{*}$ \\
\hline Cognitive Maturity & $\begin{array}{l}\mathrm{E} \\
\mathrm{C}\end{array}$ & $\begin{array}{l}73 \\
67\end{array}$ & $\begin{array}{l}42.0298 \\
42.2174\end{array}$ & $\begin{array}{l}5.6973 \\
5.5897\end{array}$ & $\begin{array}{l}.8103 \\
.7984\end{array}$ & .325 & 138 & .697 \\
\hline CCTDI Total Score & $\begin{array}{l}\mathrm{E} \\
\mathrm{C}\end{array}$ & $\begin{array}{l}73 \\
67\end{array}$ & $\begin{array}{l}318.38 \\
290.82\end{array}$ & $\begin{array}{l}24.1225 \\
15.3267\end{array}$ & $\begin{array}{l}3.7891 \\
2.9148\end{array}$ & 4.412 & 138 & $.000 *$ \\
\hline
\end{tabular}

${ }^{*}$ Significant at $p<0.05(2$-tailed).

According to Table 7, there was a statistically significant difference between the total mean of the experimental $(E)$ and the control $(C)$ groups (total mean of $E=318.38, S D=$ 24.1225 ; total mean of $C=290.82, S D=15.3267$ ). There was not any statistically significant difference in the mean posttest scores on some CCTDI subscales (for example, truth-seeking, cognitive maturity, and open- mindedness), whereas the mean posttest scores of some CCTDI subscales were significantly different (for example, analyticity, CT inquisitiveness, CT self-confidence, and systematicity). The mean posttest scores of the experimental group were significantly higher on Systematicity $(M=50.1794, S D=5.4632)$, Analyticity $(M=45.4789, S D=6.3685)$, CT Self-Confidence $(M=43.7419, S D=3.4123)$, and $C T$ Inquisitiveness $(M=48.3263, S D=5.6514)$ than the mean posttest scores of the control group, for instance, Analyticity $(M=40.2179, S D=4.9725)$, Systematicity $(\mathrm{M}=43.7317, \mathrm{SD}=5.4971), \mathrm{CT}$ Self-Confidence $(\mathrm{M}=38.9412, \mathrm{SD}=5.3497)$, and $\mathrm{CT}$ Inquisitiveness $(\mathrm{M}=43.0179, \mathrm{SD}=.7649)$.






\subsubsection{The relationship between students' achievements in essay writing skills, critical thinking ability, and dispositions toward critical thinking for Iranian students}

Table 7 provides the results of correlation analysis for AWST, E-W CTET, and CCTDI.

Table 7. Correlation Coefficients for AWST, E-W CTET, and CCTDI.

\begin{tabular}{|llrrr|}
\hline \multirow{4}{*}{ AWST } & Pearson Correlation & AWST & Ennis-Weir & \multicolumn{1}{c|}{ CCTDI } \\
& Sig. (2-tailed) & 1 & $.513^{* *}$ & $.342^{* *}$ \\
& $\mathrm{~N}$ & & .006 & .271 \\
\multirow{4}{*}{ Ennis-Weir } & Pearson Correlation & $.513^{* *}$ & 140 & 140 \\
& Sig. (2-tailed) & .006 & 1 & $.241^{* *}$ \\
& $\mathrm{~N}$ & 140 & & .517 \\
CCTDI & Pearson Correlation & $.342^{* *}$ & $.241^{* *}$ & 140 \\
& Sig. (2-tailed) & .271 & .517 & 1 \\
& $\mathrm{~N}$ & 140 & 140 & 140 \\
\hline
\end{tabular}

${ }^{* *}$. Correlation is significant at the 0.01 level (2-tailed).

According to Table 7, each instrument was positively correlated with the other two. Though the strength of the relationship was different. There was a moderate relationship between the scores of the E-W CTET and the AWST, Pearson $r=.513, n=73, p<.05$ (i.e., $.006<.01)$. This implies that the high scores of the Ennis-Weir's critical thinking ability test are correlated with the high scores of the academic writing skill test. On the other hand, the correlation between other instruments is small. There was a statistically significant difference between the experimental group and the control group in academic writing tests and Ennis-Weir posttest scores. The results of the CCTDI showed no statistically significant differences between the experimental and the control groups in certain dispositional dimensions. Students in the experimental group were more capable of using their critical thinking skills. They were able to use their critical thinking skills more in academic and reallife situations than those who did not receive instruction. Modest and weak relationships were found between the instruments.

\section{Discussion.}

The results of the essay test served as data to determine whether students who were taught to use these techniques were better able to think critically and write thoughtfully in their academic writing test than students who were not trained to use these techniques. The data were then analyzed via descriptive statistics and independent-samples $t$-test using the results of the students on the test. The extent of the difference between these two groups indicated that these critical thinking instructions had an educative and statistically significant impact on students' ability to perform better in writing.

Significant pedagogical implications of this study are in line with those of Chaffee, McMahoon and Stout (2002) and Worrell and Profetto-McGrath (2007) who argued that using critical thinking strategies and activities with different levels of language competence in English language classes can increase the students' level of thinking and at the same

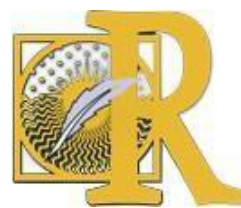


time help language learners to promote their listening, speaking, reading and writing skills. Critical thinking techniques can provide students with tools to help them overcome hurdles and develop language learning skills. Research indicated that critical thinking in writing essays extends learning experience and makes language learning more meaningful for students; it is a vehicle through which their potential can gradually emerge in language learning process (Lipman, 2003).

The results of the study indicated that critical thinking techniques may be an operative intervention for learning and can improve or promote students' essay writing ability. Therefore, critical thinking and essay writing ability have been positively influenced by the explicit instruction of critical thinking in English essay writing. Mirman and Tishman (1988) and Scanlan (2006) maintained that the critical thinking skills entrenched in the course and integrated into language education can directly lead to an improvement in language learning.

With regard to the effectiveness of integrating critical thinking into the writing course content, the results of this study support the results of earlier research. For example, Clark (2004) supported the use of CT in academic writing. The integration of CT into the course content can have a significant and predictable impact on critical thinking skills and better student academic performance. Concerning the effectiveness of explicit critical thinking instruction on academic subjects, the results of this study also supported the results of Coughlin's (2010) earlier studies. In relation to this, Coughlin (2010) argued that research on $21^{\text {st }}$ century skills shows that students' success is more related to critical thinking than traditional teaching methods.

To test the students' ability to apply the critical thinking skills gained through reasoning to everyday reasoning tasks, the experimental and control groups were administered the Ennis-Weir critical thinking essay test during the first and last weeks of the course. The topic of the writing test was the parking problem people faced in a small town. Students were required to give response to the arguments made by the citizens who wrote the letter, and finally evaluate whether the letter provides enough support for the author's suggested solution. The Ennis-Weir results indicated that the experimental group achievement was significantly higher than that of the control group, $t(138)=8.719,(p<.05)$. Although the pretest means were similar, posttest means of the experimental group increased to a larger extent. Even though the gain in the control group was not obtained as much as the experimental group, the control group also showed a statistically significant improvement from the pretest to the posttest. Significant increases from pretest to posttest were observed. However, students who received instruction in CT performed better on the tasks which required them to evaluate written arguments compared to their counterparts who did not receive CT instruction.

Although the pretest to posttest increases in the scores of the experimental group and the control group were not unexpected, the increase in the mean score of the control group from the pretest to the posttest was unexpected, though satisfactory. A possible explanation is that either the traditional teaching used in academic writing courses in general education helped students develop critical thinking skills, or because students' previous critical thinking skills significantly affected their critical thinking performance (Quitadamo and Kurtz, 2007).




Specifically, students with the highest critical thinking skills exhibited the greatest performance gains, while those with lower initial skills were at a relative disadvantage. The fact that the previous critical thinking ability had a great influence on the critical thinking performance in this study increased the generalizability of observation and highlighted its importance. To summarize, students who did not receive explicit instruction in CT may not have reached the same potential as their counterparts who received such instructions. This is not because they lacked the cognitive ability to perform, rather it was due to lack of appropriate tools to build their knowledge. The control groups showed a higher gain in the mean pretest scores compared to the experimental group. This might reflect the role of background knowledge which has been emphasized by some researchers (Case, 2005; Kennedy et al., 1991; Willingham, 2008).

The results of this study showed that we should use some form of writing to meet the challenge of improving critical thinking ability. However, it is not totally clear how to apply critical thinking through writing. As mentioned before, critical thinking is a complex skill, or a set of techniques. Therefore, not any method of writing that enhances critical thinking can, of course, be accomplished by adding one or two new writing tasks to the course. However, solving this problem requires a new and comprehensive teaching method, focusing specifically on analytical writing (Clark, 2004). Consequently, this finding underlines the importance of providing explicit instruction in critical thinking, rather than merely considering critical thinking as an implicit objective of the course.

In order to determine students' dispositions toward critical thinking, students in both groups were administered the California Critical Thinking Dispositions Inventory (CCTDI) both at pre-and-post-instructions of the course. Results of the statistical analyses of the scores indicated that the posttest means of the experimental group were significantly different from the posttest means of the control group on the CCTDI overall scores (Experimental $\mathrm{M}=318.38$, and Control $\mathrm{M}=290.82$ ), but the mean posttest scale scores were too small for (Truth-seeking: Experimental $M=45.2145$, Control $M=44.3697$; Open-mindedness: Experimental $\mathrm{M}=43.4153$, Control $\mathrm{M}=42.3265$; Analyticity: Experimental $M=45.4789$, Control $M=40.2179$; Systematicity: Experimental $M=50.1794$, Control $M=43.7317$; $C T$ self-confidence: Experimental $M=43.7419$, Control $M=38.9412$; CT Inquisitiveness: Experimental $M=48.3263$, Control $M=43.0179$; Cognitive Maturity: Experimental $\mathrm{M}=42.0298$, Control $\mathrm{M}=42.2174$ ).

Students in the experimental group in this study had positive dispositions toward both overall CTD and CDT scale scores. This is encouraging because the findings suggested that students are keen to apply their critical thinking skills when circumstances require. The control group had positive and ambivalent dispositions toward CT self-confidence and analyticity.

Although the overall improvement in critical thinking dispositions in posttests is encouraging, the mean posttest scores of certain individual scales (open-mindedness, cognitive maturity, and truth-seeking) of CTD did not show significant differences. The similarity of the mean scores in this study showed that exposure to educational experience, whether in the form of explicit teaching of critical thinking or traditional teaching methods, does not seem to make these students learn truth-seeking, open-mindedness, and cognitive maturity. For researchers and those involved in the education of these students,

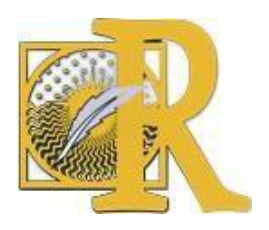


this is certainly not satisfying news and idea because people hope to promote the disposition toward truth-seeking, openness and cognitive maturity through the education process.

The results of this study showed that there was a statistically significant difference in the overall CTD between the experimental and the control groups (Experiment $M=318.38$, Control $M=290.82$ ). This does imply that one semester of teaching techniques will affect students' critical thinking dispositions although the teaching in CT did not emphasize this variable. The average total score of 318.38 in this study was lower than that of Facione and Facione (1997) $(M=308)$. The total CTD was also compared with the results of Reed (1998) (Pretest: $M=303.35$ and Posttest: $M=303.90$ ), indicating no statistically significant difference between the pretest and posttest overall CCTDI scores.

Regarding the relationship between students' achievements in essay writing skills, critical thinking ability, and dispositions toward critical thinking, the results of this study showed that test scores for each of the three instruments were positively related to each of the other two instruments, but the strength of this relationship was different. The strongest relationship was found between academic writing and the Ennis-Weir Critical Thinking Ability Test $(r=$ .513). This means that $17.1 \%$ of shared variance existed between the two variables, indicating a moderate effect. This moderate relationship might be anticipated because the ability to write thoughtfully necessitates that students evaluate, analyze, synthesize, and interpret the information critically which merely focus on main learning skills for survival and the skills which students need to succeed in university assignments. The relationship between academic essay writing and CCTDI was found to be $(r=.342)$, indicating a small positive correlation and $4.2 \%$ of the shared variance. Each of these two tools was correlated in some way to the general ability of critical thinking.

The Ennis-Weir and the CCTDI also had a small, positive relationship $(r=.241)$ with a $1.24 \%$ of shared variance between them. Therefore, this $1.24 \%$ of variability suggested a small effect. Each of these two tools was correlated to a main component of CT skills, i.e. the Ennis-Weir test is primarily used for reasoning skills and CCTDI for critical thinking. Experts found that the disposition toward thinking critically is as important to those who are considered critical thinkers as is the necessity of having cognitive skills. Lack of strength in the relationship between the two instruments in this study might suggest that the instructor did not receive special training before developing the teaching material practice and providing explicit instruction in critical thinking. The researcher also found that it is important that educators receive special training interventions in critical thinking teachings to have the greatest effect size compared to studies in which course curriculum and critical thinking standards or critical thinking were merely aligned. Therefore, successful interventions might necessitate professional development for teachers who focus on teaching critical thinking (Abrami et al., 2008). 


\section{Conclusion.}

This study was intended to empirically investigate the effectiveness of explicit teaching of critical thinking on Iranian students' academic writing performance, critical thinking ability, and their critical thinking dispositions. The results indicated that there were statistically significant differences between the mean scores of the experimental and the control groups. The results also showed that some CCTDI subscales were not significantly different at the posttest such as, truth-seeking, cognitive maturity, and open- mindedness, whereas the mean posttest scores of other CCTDI subscales were significantly different such as, analyticity, CT inquisitiveness, CT self-confidence, and systematicity. The experimental group had a higher score in the academic writing test compared with the control group. Changes in students' critical thinking ability, academic writing performance, and their critical thinking dispositions suggest that the CT techniques have been fruitful, and more efforts should be made to integrate the explicit instruction in critical thinking into academic courses.

\section{Pedagogical Implications.}

The study was carried out in a natural educational milieu which included many variables such as students' dropping out of university, and many other challenges. In spite of all these challenges, the results of the study showed that there were large effect sizes on the instruments which examined students' learning to write academic essays, implying that teaching critical thinking skills can have a great influence on students' CT ability. Such a study can provide a strong incentive to pay closer attention to the possible consequences of incorporating CT techniques into educational courses. In fact, the results of this study on the effectiveness of critical thinking teaching techniques and materials are designed to improve students' critical thinking skills and have significant implications on several groups including instructors, business managers, and society.

From the perspective of educators, prospective employers and society as a whole, cultivating students' critical thinking is one of the main tasks of the education system. Critical thinking skills, such as analyzing complex problems and situations and generating solutions, establishing connections and transferring insights into new environments, and formulating decision criteria are necessary conditions for social success. If educators really want their students to have a high level of thinking skills, and if society really needs critical thinking, educators must influence teachers and institutions and incorporate explicit critical thinking instruction into all levels of school education in various academicfields.

For teachers, recognizing the nature of critical thinking and the way in which its instruction is done through this method is crucial. There is little evidence that even if a teacher is a good critical thinker and uses critical thinking when teaching a course will help students increase their critical thinking ability. On the other hand, much evidence prevails including this study which shows that if we want our students to think critically, we must explicitly teach them how to do so. In this study, critical thinking instruction is both direct and intense. By the same token, in order to improve students' critical thinking ability, they must explicitly and thoroughly be taught the core critical thinking skills components (Delphi Research Report, 1990) and should be taught techniques and materials frequently. These teaching techniques and materials must be thoroughly incorporated into the course content, rather than being 
introduced or used several times in a semester. Implicit modeling of critical thinking combined with discrete courses that provide critical thinking practices cannot be effective for most students. The most important implication of this study might be realizing the need for explicit and intense instruction of critical thinking.

Another implication of this study is that teachers could also reasonably think that a challenge that is associated with learning about critical thinking may have a positive or negative influence on learners' dispositions or motivations to use critical thinking. This study suggests that this concern is necessarily valid. One finding of this study was that students' overall disposition of critical thinking as measured by the California Critical Thinking Dispositions Inventory (CCTDI) to learn to think critically and apply skills of critical thinking when necessary seemed to be significantly different from students' attitudes toward the traditional approach to learning. Although some aspects of the disposition, such as open-mindedness, truth-seeking, and cognitive maturity between the experimental and control groups did not differ, the results of CCTDI suggested that the two groups differed significantly in overall attitudes. This has a significant implication for teachers or instructors that explicit teaching in critical thinking can also bring about motivational or attitudinallearning.

\section{References}

- Abrami, P. C., Bernard, R. M., Borokhovski, E., Wade, A., Surkes, M. A., Tamim, R., \& Zhang, D. (2008). Instructional interventions affecting critical thinking skills and dispositions: A stage 1 meta-analysis. Review of Educational Research, 78(4), 11021134.

- American Philosophical Association [APA] (1990). Critical Thinking: A Statement of Expert Consensus for Purposes of Educational Assessment and Instruction, The Delphi Report: Research Findings and Recommendations Prepared for the Committee on PreCollege Philosophy. P. Facione, (Project Director). ERIC Doc. No. ED 315-423.

- Bartlett, F.C. (1958). Thinking: An experimental and social study. London: Unwin University Books.

- Beyer, B. K. (1985). Teaching critical thinking: A direct approach. Social Education, 49(4), 297-303.

- Bloom, B.S. (1956). Taxonomy of educational objectives: Classification of educational goals. New York: Longmans, Green.

- Case, R. (2005). Moving critical thinking to the main stage. Education Canada, 45(2), 4549.

- Chaffee, J., McMahon, C. \& Stout, B. (2002). Critical thinking thoughtful writing. New York: Houghton Mifflin.

- Clark, D. (2004). Is professional writing relevant? A model for action research. Technical Communication Quarterly, 13(3), 307-323.

- Condon, W., \& Kelly-Riley, D. (2004). Assessing and teaching what we value: The relationship between college-level writing and critical thinking abilities. Assessing Writing, 9(1), 56-75.

- Coughlin, E. (2010). High schools at a crossroads. Educational Leadership, 67(7), 48-60. 
- Dewey, J. (1933a). How we think: A restatement of the relation of reflective thinking to the educative process. Chicago: Henry Regnery.

- Ennis, R. H. (1985). Critical thinking and the curriculum. National Forum, 65(1), 28-31.

- Ennis, R. H. (1987). A taxonomy of critical thinking dispositions and abilities. In J. B. Baron \& R. J. Sternberg (Eds.), Teaching Thinking Skills. Theory and Practice (pp. 9-26). N. York: W. H. Freeman and Company.

- Ennis, R. H. (2005). Supplement to the test/manual entitled he Ennis-Weir critical thinking essay test. Urbana, IL: The Illinois Critical Thinking Project.

- Ennis, R. H., \& Weir, E. E. (1985). The Ennis-Weir critical thinking essay test: An instrument for teaching and testing. Midwest Publications.

- Facione, N. C., \& Facione, P. A. (1997). Critical thinking assessment in nursing education programs: An aggregate data analysis. Millbrae: California Academic Press.

- Facione, P. A. (1990). Critical thinking: A statement of expert consensus for purposes of educational assessment and instruction. Millbrae, CA: The California Academic Press.

- Facione, P. A. (2000). The disposition toward critical thinking: Its character, measurement, and relationship to critical thinking skill. Informal logic, 20(1), 61-84.

- Facione, P. A., Sanchez, C. A., Facione, N. C., \& Gainen, J. (1995). The disposition toward critical thinking. The Journal of General Education, 44(1), 1-25.

- Fasko, D. (2003). Critical thinking: origins, historical development, future direction. In D. Fasko (Ed.), Critical thinking and reasoning: Current research, theory and practice (pp.320). Cresskill, NJ: Hampton Press.

- Gilhooly, K. (1996). Thinking: Directive, undirected, and creative. Amsterdam: Academic Press.

- Halonen, J. S. (1995). Demystifying critical thinking. Teaching of psychology, 22(1), 75-81.

- Halpern, D. F. (1998). Teaching critical thinking for transfer across domains. American Psychologist, 53(4), 449-455.

- Halpern, D. F. (2007). The nature and nurture of critical thinking. In R. J. Sternberg, H. L. Roediger III, \& D. F. Halpern (Eds.), Critical thinking in psychology (pp. 1-14). New York, NY, US: Cambridge University Press.

- Hinkel, E. (2003). Teaching academic ESL writing: Practical techniques in vocabulary and grammar. New York: Routledge.

- Jones, P. J., \& Haydon, D. (Eds.). (2012). Putting it into practice: Developing student critical thinking skills in teacher education. Charlotte, NC: Information Age.

- Kennedy, M., Fisher, M. B., \& Ennis, R. H. (1991). Critical thinking: Literature review and needed research. Educational Values and Cognitive Instruction, 15 (3). 111-126.

- King, A. (1994). Inquiry as a tool in critical thinking. In D. F. Halpern (Ed.), Changing college classrooms: New teaching and learning strategies for an increasingly complex world (pp. 13-38). San Francisco: Jossey-Bass.

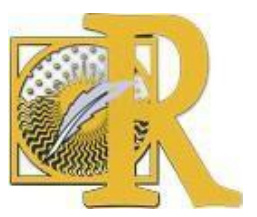


- Kurfiss, J. (1988). Critical thinking: Theory, research, practice and possibilities. Washington: Higher Education.

- Lewis, A., \& Smith, D. (1993). Defining higher order thinking. Theory into Practice, 32(3), 131-137.

- Lipman, M. (1988). Critical thinking: What can it be? Educational Leadership, 46(1), 3843.

- Lipman, M. (2003). Thinking in education. Cambridge: Cambridge University Press.

- McPeck, J. (1981). Critical thinking and education. New York: St. Martin's.

- Mirman, J., \& Tishman, S. (1988). Infusing thinking through connections. Educational Leadership, 45(7), 64-65.

- Paul, R. \& Elder, L. (2007). Critical thinking: The art of Socratic questioning. Journal of Developmental Education, 31(1), 36-37.

- Paul, R. (1985). The critical thinking movement. National Forum, 65(1), 23-32.

- Paul, R. (1992). Critical thinking: What, why, and how. New directions for community colleges, 92(77), 3-24.

- Paul, R. and Elder, L. (2008). The miniature guide to critical thinking concepts and tools. Dillon Beach: Foundation for Critical Thinking Press.

- Paul, R., \& Elder, L. (2001). Critical thinking: Tools for taking charge of your learning and your life. Upper Saddle River, NJ: Prentice Hall.

- Pescatore, C. (2007). Current events as empowering literacy: For English and social studies teachers. Journal of Adolescent \& Adult Literacy, 51(4), 326-339.

- Quitadamo, I. J., \& Kurtz, M. J. (2007). Learning to improve: using writing to increase critical thinking performance in general education biology. CBE-Life Sciences Education, 6(2), 140-154.

- Ramsden, P., \& Moses, I. (1992). Associations between research and teaching in Australian higher education. Higher Education, 23(3), 273-295.

- Reed, J. H. (1998). Effect of a model for critical thinking on students' achievement in primary source document analysis (PhD dissertation). University of south Florida, The United States.

- Reed, J. H. (1998). Effect of a model for critical thinking on students' achievement in primary source document analysis (PhD dissertation). University of south Florida, The United States.

- Scanlan, J.S. (2006). The effects of Richard Paul's universal elements and standards of reasoning on twelfth grade composition (Master's thesis). Alliant International University, USA.

- Sims, M. (2014). The write stuff: Thinking through essays. USA: Pearson Prentice Hall.

- Steele, C. M. (1997). A threat in the air: How stereotypes shape intellectual identity and performance. American Psychologist, 52(6),613-629.

- Sternberg, R. J. (1986). Critical thinking: Its nature, measurement, and improvement. Washington, D. C.: National Institute of Education.

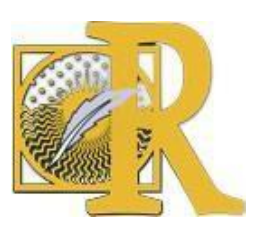


- Tsui, L. (2002). Fostering critical thinking through effective pedagogy: Evidence from four institutional case studies. The Journal of Higher Education, 73(6), 740-763.

- Willingham, D. T. (2008). Critical thinking: Why is it so hard to teach? Arts Education Policy Review, 109(4), 21-32.

- Worrell, J. A., \& Profetto-McGrath, J. (2007). Critical thinking as an outcome of contextbased learning among post RN students: A literature review. Nurse Education Today, 27(5), 420-426. 